\title{
Szigetvár az 1566. évi török hadjárat idején. $A$ vár és a város történeti és régészeti kutatásai
}

\author{
HANCZ ERIKA \\ Pécsi Tudományegyetem Régészet Tanszék \\ H-7624 Pécs, Rókus utca 2. M. ép. I. em. 105., hancz.erika@pte.hu
}

\begin{abstract}
Hancz, E.: Szigetvár in the time of the 1566 Szigetvár campaign. Historical and archaeological investigations of the castle and the city

Abstract: Using the written and archaeological sources, my aim is to give a statement of the facts about Szigetvár during the last campaign of Süleyman the Magnificent in 1566. The major part of the examination was done with the help of the chronicles, mainly the so called Sigetvar-nâmes, the separate Ottoman chronicles about the campaign and the results of the earlier and new archaeological excavations.
\end{abstract}

Keywords: Ottoman Empire, 1566 Szigetvár campaign, Ottoman era Hungary, historical and archaeological investigations, Szigetvár castle

\section{Bevezető}

Nagy Szülejmán szultán (1520. szept. 30. - 1566. szept. 7.) trónra lépését követően a nyugati fronton indított oszmán hadjáratok ráébresztették az európai országokat arra, hogy a török külpolitikában egy számukra igen kedvezőtlen és fenyegető változás állt be. A keleti hadszíntérről ugyanis egyre inkább a nyugati hadszíntérre irányult az Oszmán Birodalom figyelme. Oszmán fősereg tulajdonképpen 1521-ig, Nándorfehérvár bevételéig nem harcolt magyar földön, így Szülejmán kezdte el a szisztematikus hódítást a Magyar Királyság területén.

Az oszmánok magyarországi elöretörésével számos más európai terület is közvetlen veszélybe került Kelet-Közép-Európában: így az egyes osztrák tartományok (Karintia, Krajna, Stájerország), Észak-Itália és a krími tatárok révén Lengyelország is. De Németország Kölnnel együtt közvetett módon szintén távoli oszmán célpontként szerepelt. A 16. században a nyugati szárazföldi hadszíntéren Magyarország, majd pedig Bécs jelentette az oszmán hódítás fő célpontját. A Habsburgoknak már csak ezért is hadsereget kellett szervezniük a török becsapások idején. Ugyanakkor ez a költségesen felszerelt hadsereg csak végső esetben ütközött meg a törökökkel, és Szigetvár esetében pl. kisebb mozdulatoktól eltekintve végig passzív maradt.

A törökök nem 1566-ban indultak először Szigetvár ellen, hanem már voltak sikertelen próbálkozásaik: 1555-ben és 1556-ban. Nagy Szülejmán utolsó hadjárata Szigetvár (és talán Bécs) ellen irányult, és Szigetvár falai előtt érte a szultánt a halál. Ekkor már két szerdárt, azaz hadvezért is kinevezett: a főhad élén Szokollu Mehmed pasa nagyvezír, a Gyula felé vonuló had élén Pertev pasa másodvezír állt.

A korábbi hadjáratoktól eltérően Szülejmán szultán 1566. évi hadjáratán kevés kivételtől eltekintve az összes fontos állami méltóság részt vett. Jelen voltak a vezírek, a nisándzsi (a szultáni kézjel rajzolója), a defterdárok, a kádiaszker, több vilájet vezetője és a szultáni palota szolgálattevői is. A források eltérően vélekednek a török had létszámáról, de kijelenthetjük, hogy egy minimum ötvenezer fős török fősereg érkezett 1566-ban Szigetvár alá.

\section{A források}

Nagy Szülejmán uralkodásának idején az Oszmán Birodalomban többnyire török nyelvű történelmi művek születtek, de kis számban perzsa és arab nyelvű krónikák is ránk maradtak. A kor történelmét verses és prózai formában is megörökítették. Az egyes politikai lépéseket ugyanis nemcsak a külföld, hanem a birodalom alattvalói számára is meg kellett magyarázni. A szultán a haditetteit igyekezett megörökíttetni az utókor számára is. Rendszeres fizetésben részesített olyan történetírókat, akik megírták a kor eseménytörténetét. $A$ kor két hivatalos történetírója Fethulláh Árif cselebi (hivatali ideje: 1520-1561) és Eflatún Sírvání (1561-1569) voltak. Ez utóbbi a szigetvári hadjárat legfontosabb eseményeit is összefoglalta. Mellettük a szultán és a nagyvezír környezetében élő méltóságok számára is előnyökkel járt, ha egy-egy eseményt, hadjáratot vagy időszakot megörökítő műveket készítettek és átnyújtottak a szultánnak, vagy egy-egy magas rangú méltóságnak, korszakunkban főleg Szokollu Mehmed pasa nagyvezírnek.

Az egyik legfőbb forráscsoportot a hadjárattal foglalkozó, két kivétellel mindmáig kiadatlan oszmán-török nyelvű önálló művek, az ún. Szigetvár-námék alkotják (a kivételt Ahmed Feridun: Nüzhetü'l-eszrári'l-ahbár der szefer-i Szigetvár, 'A szigetvári hadjárat titkos híreinek kelleme' című műve jelenti, melynek kritikai kiadása először 2010-ben jelent meg, illetve Meráhi verses Feth-náme-i szefer-i Szigetvár című múve 'A szigetvári hadjárat 
győzelmi jelentése, 2012-ben). ${ }^{1}$ A törökországi és bécsi levéltári és könyvtári kutatómunka folyamán az általam ismert, a szigetvári hadjáratot megörökítő kilenc oszmán krónika közül ötnek találtam meg a kéziratait (szám szerint 15-öt). A fennmaradt krónikák egy verses költemény kivételével prózai művek. A Szigetvár-námék közvetlenül a szigetvári hadjárat után, még a 16. században keletkeztek.

A jelenleg ismert Szigetvár-námék a következők:

I. Ágehi Manszúr: Feth-náme-i kale-i Szigetvár / Táríh-i gazá-i Szigetvár (A szigetvári vár győzelmi jelentése / A szigetvári szent harc története)

II. Ahmed Feridun: Nüzhetü'l-eszrári'l-ahbár der sefer-i Szigetvár (A szigetvári hadjárat titkos híreinek kelleme)

III. Gelibolulu Musztafa Áli: Heft medzslisz (Kánuni'nin 974 Szigetvár szeferi táríhcseszi) (Hét gyűlés. A Törvényhozó 974./1566. évi hadjáratának története)

IV. Tárih-i Szigetvár/Heft dászitán (Szigetvár története, avagy a Hét történet)

V. Meráhi: Feth-náme-i szefer-i Szigetvár (A szigetvári hadjárat győzelmi jelentése)

VI. Ásik cselebi: Szigetvár-náme

VII. Szejfulláh Szejfi: Szigetvár-náme

VIII. Ali Mehmed cselebi: Szigetvár-náme

IX. Szejjid Lokman: Szigetvár-náme

Ezek közül főleg az első három szolgáltat bővebb adatokat a hadjáratra. Kiemelkedő krónika Szigetvár vonatkozásában Kátib Mohammed Záim: Dzsámiü't-tevárih (Történetek gyűjteménye) című műve is, melyben a hadjáratot röviden ismerteti. ${ }^{2}$ A krónikának nincs teljes kiadása. ${ }^{3}$ Mivel Kátib Mohammed Záim élt a magyarországi török hódoltságban, és ismerte a helyi viszonyokat, továbbá Szokollu Mehmed pasa titkáraként első kézből sok információt szerezhetett a szigetvári hadjáratról, műve jól használható forrás az 1566. évi hadjáratra vonatkozóan.

Külön meg kell említeni azokat a történetírókat is, akik múveiket Szülejmán korának vége felé lezajlott események ismertetésével kezdték. Közéjük tartozik Szelániki Musztafa efendi, aki az 1563-tól 1600-ig tartó eseményeket örökítette meg. Mivel a szerző személyesen is részt vett Szülejmán szigetvári hadjáratában, a korra vonatkozóan értékes forrásnak tekinthető. ${ }^{4}$ Ugyanide sorolható Haszanbejzáde (1565-1636) ${ }^{5}$ és Szolakzáde (1590-1657) ${ }^{6}$ múve, Pecsevi (1574-1649) Táríhja, ${ }^{7}$ Evlia cselebi (1611-1685?) Szejahat-náméja ${ }^{8}$ is, melyek jóval később keletkeztek ugyan, de szintén fontos forrásnak tekinthetők a szigetvári hadjárat eseményeinek és Szigetvár erősségének leírásához.

Az elbeszélő források által szolgáltatott történeti adatokat össze kell vetni az okleveles forrásanyaggal is. A krónikák ugyanis torzíthatnak és bizonyos eseményeket az adott ideológiai magyarázatok végett felnagyíthatnak, vagy el is titkolhatnak. Emellett a két szembenálló fél közötti levelezés, valamint a követjelentések és az egyes elöljáróknak elküldött utasítások segítségével nyomon követhetjük a hadjáratra vonatkozóan mindkét fél értesüléseit, előkészületeit és későbbi lépéseit is. A forráscsoport vizsgálatával kiegészíthetjük azt a képet, mely az oszmán krónikák török-központú leírására támaszkodik. ${ }^{9}$ Nagy előnye még, hogy sokszor kis események, aprólékos adatok, számok és nevek szerepelnek bennük, melyek még a krónikáink értelmezési esélyeit is javítják. Az Isztambuli Miniszterelnökségi Levéltárban őrzött, a szultáni tanács szigetvári hadjárathoz vezető időszakra vonatkozó, 1564-65. évi magyar vonatkozású rendeleteit Dávid Géza és Fodor Pál közös forráskiadványban közreadta. ${ }^{10} \mathrm{Az}$ azt követő mühimmék török kiadása is megjelent, de a hadjárat második felére vonatkozó iratanyag sajnos még nem került elő. Ezek mellett a bécsi levéltár minoritenplatzi részlege is bőven tartalmaz okleveles iratanyagot, föleg a hadjárat előzményeire és következményeire vonatkozóan. Ez utóbbi magyar, latin, német és oszmán-török nyelvŭ iratcsoport az elbeszélő források hiányait pótolhatja.

1 Vatin 2010., Arslantürk - Kaçar 2013

2 Kátib Mohammed Záim 1532-ben született. Az 1570-es években Ahmed Feridun után ő lett Szokollu Mehmed nagyvezír írnoka. 1579 után halt meg, halálának pontos dátuma nem ismert, Török történetírók II. 365.

3 Török történetírók II. 364-389. A fordítás alapja: Nationalsbibliothek Wien, Hist. Osman 2., 321 folio.

4 Selâniki 1999

5 Hasanbeyzâde 2004.

6 Kiadásai: 1855: Isztambul (csak a Mehmed cselebi időszakáig tartó események arab betűs átirata), 1880: Isztambul (a teljes mű arab betűs átirata), 1927: Isztambul, 1989: Kültür Bakanlığı Yayınları, és Ankara Sevinç Yayınları: törökországi török nyelven nem kritikai kiadásként Vahid Çabuk adta ki két kötetben. A szigetvári hadjárat leírását a II. kötet tartalmazza, Solakzâde 1989.

7 Târih-i Peçevi I

8 Kiadásai: Evlia 1318., Evlia 1908., Evlia 1985., Evlia 2002

9 Ebben a témában megjelent cikkem: Nagy Szülejmán szigetvári hadjáratára vonatkozó levelek a bécsi Staatsarchivban, Id. Hancz 2009.

10 Dávid - Fodor 2009. 
A történeti források adatait már korábbi és saját régészeti eredményekkel is alátámaszhatjuk, de e téren is még további kutatásokra van szükség, Id. később."

\section{Szigetvár a török hadjárat idején}

\section{Szigetvár török leírásai}

Ágehi Szigetvár-náméjában így szerepel Szigetvár ${ }_{\text {"I }}(A$ vár) a jól védett birodalom területén egy tó belsejében helyezkedett el. Két erős vár volt, melyeket egy-egy híddal kötöttek össze." ${ }^{12}$ Ezt követően szintén Ágehi krónikájának leírása szerint Semsz Ahmed pasa ruméliai beglerbég, valamint a mellé rendelt két szandzsákbég már Szigetvár mellett kémlelte a várat akkor, amikor a szultáni tábor helyét is kijelölték. Ekkor a vár felé néztek, és „Látták, hogy egy nagy, hatalmas vár, az egyik része felhö-szerüen az ég palotájáig ér, és erődített bástyája az ég csúcsával azonos (...). Egy csodálatos vár és csodás erősség mindannak aki látja, a körforgás mérnökeinek idejében nem láttak még ehhez foghatót. Minden oldal falának hossza és minősége tekintetében a tudósok felfogása gyenge és erőtlen. A rajta lévő hadiszerek és háborús kellékek említése során a bölcsek és tisztelt emberek bámulatba esnek. Sárkányhoz hasonló és kígyó kinézetü, elefánt-növésü és oroszlán-árnyékú, tüzet lövellö, zajos, mennydörgö, faltörő elefánt- és hatalmas ágyúkkal és zarbuzánokkal együtt mintha egy vasból épült hegy lenne. A hitetlen ellenség, illetve a benne lévő felügyeló oorparancsnok, az átkozott hitetlen Zrínyi fia (Zrín ogli) véleménye az volt, hogy ezt az erös várat lehetetlen elfoglalni."13 Az ostromot illetően Ágehi szerint korábban a következő szultáni parancsot adták ki: Kızıl Ahmedli Musztafa pasa ötödik vezír a vár keleti oldalát lövesse, Zál Mahmud anatóliai beglerbég

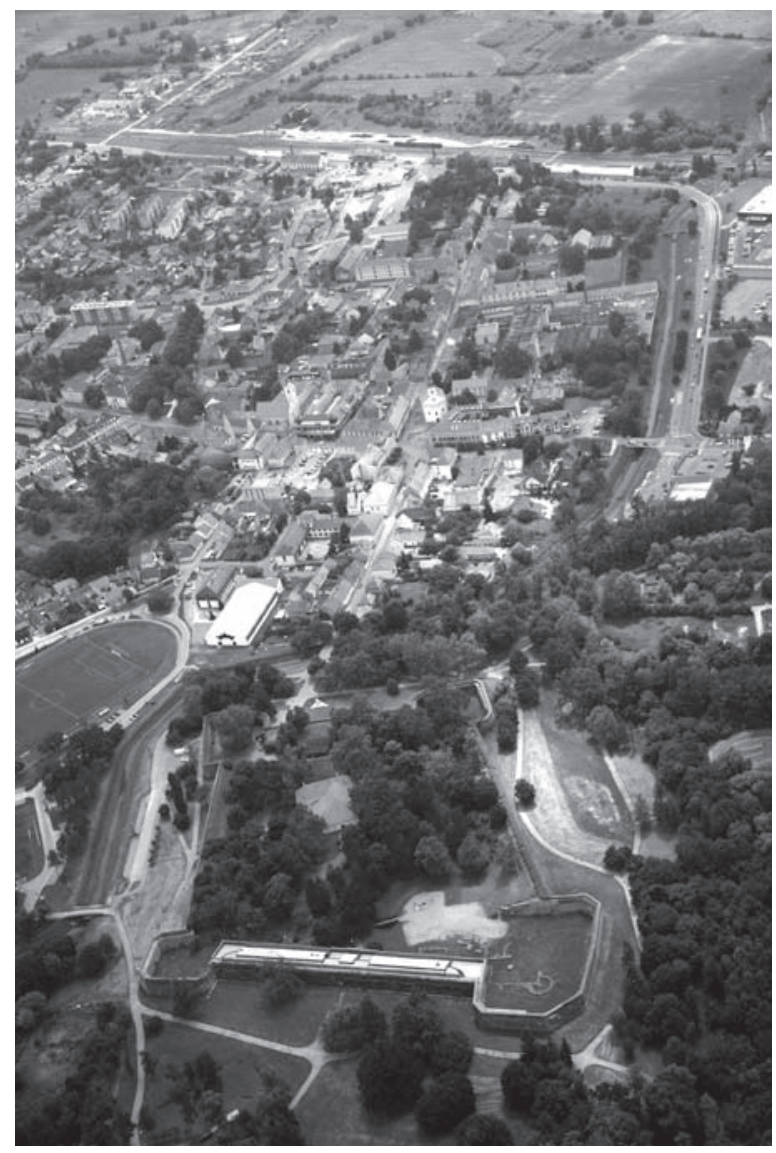

1. kép: Szigetvárról készült légifotó, észak felöl (A szerző felvétele) pedig vegye körbe Szigetvárt. ${ }^{14}$

Szelániki más információkat is közölt. Szerinte is egy nagyon erős várról van szó. A vár néhány bástyáját vörös posztóval, a belső vár tornyának csúcsát pedig ónnal díszítették a védők. A külvárost vizesárok övezte, melyen egy híd ívelt át. A külső földvár falát olyan erősnek írta le, hogy a védők kocsikkal is tudtak közlekedni rajta. A védőknek bőven volt élelmük és lőporuk is. ${ }^{15}$

A szintén szemtanú Ahmed Feridun, Szokollu Mehmed pasa titoknoka és írnoka, „négy várból álló" erősségnek nevezte Szigetvárt, és csak rövid leírást adott az első szemrevételezés során, mely szerint a „négy vár" egy „határtalan” tóban helyezkedett el, bástyái az égig értek, és ágyúi a vár közelében mindent eltaláltak. ${ }^{16}$

Álinál a vár szerkezetére vonatkozóan a következőt találjuk: nála az Újváros palánkként, az Óváros belső palánkként, a külső vár hiszárként (erődként) és a belső vár belső hiszárként szerepel. Az erősséghez vezető utakat a védők elárasztották vízzel, így az megközelíthetetlenné vált. A vár egyik oldala ingoványos, a másik oldala áthatolhatatlan térség, és közepén helyezkedik el a külső és belső vár együttese. ${ }^{17}$ Egy másik helyen pedig úgy nyilatkozott, hogy a sáncokkal párhuzamos falak három emelet magasak voltak, és az ellenséges ágyúlövedékek nem érték el. A párkány magassága 12 könyök, vastagsága 5 könyöknél nagyobb, és ezért megvédte a benne lévőket. ${ }^{18}$

11 A szigetvári hadjáratra vonatkozó ismereteinket a régi és újabb források, régészeti adatok fényében egy doktori disszertációban foglalom össze, melyet az ELTE Történettudományi Doktori Iskola „Az Oszmán Birodalom, a magyarországi török hódoltság és a Török Köztársaság története" doktori programján nyújtottam be. Ebben a hadjárat előzményeire, előkészületeire, menetére, a résztvevő személyekre és a következményeire is részletesen kitérek. Itt most a terjedelem rövidsége miatt csak az erősség 1566. évi kinézetére vonatkozó adatokat összesíthetem. Emellett hosszú távú projektként Szigetvár török korának komplex kutatását is megkezdtük.

12 Ágehi A 10a-b.

13 Ágehi A 31b-32a.

14 Ágehi A 35b.

15 Selâniki 1999. I. 28., Thúry 1981. 211. Thúry József szerint téved abban, hogy németek is lettek volna a várban, és ezt mi is elfogadjuk.

16 Ahmed Feridun A 21b, Vatin 2010. 179.

17 Heft meclis A 31a.

18 Heft meclis A 32a-32b. 


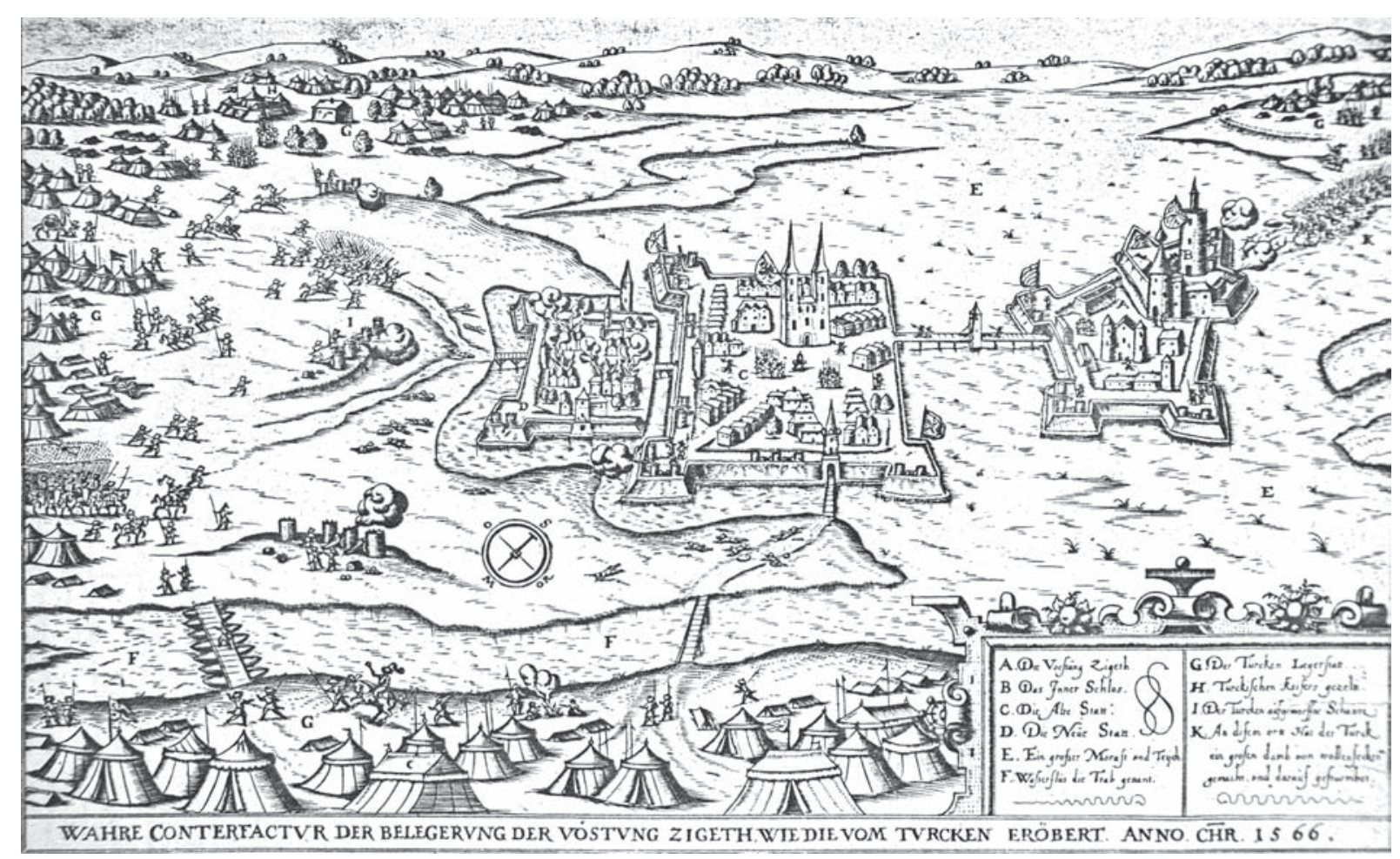

2. kép: Johann Siehmacher: Szigetvár ostroma. 17. századi rézmetszet

(Egykori Zrínyi Miklós Múzeum, Helytörténeti Gyüjtemény Sz.55.291.H.)

\section{A vár(ak) és a város(ok)}

A négy részből álló Szigetvár korabeli kinézetére vonatkozóan az itt szolgáló magyarok és külföldiek beszámolói, illetőleg régészeti adatok is rendelkezésünkre állnak. ${ }^{19}$ Budina Sámuel krónikájában a szemtanú Cserenko Ferencet követve a következő leírás található Szigetvárról: mesterségesen és természetes módon megerődített vár, mely egy mocsaras területen, Szlavónia határán található. ${ }^{20}$

Az erősség élelmezésének alapját 201 holdnyi majorsága adta. A királyi kertek a várostól délre helyezkedtek el. ${ }^{21}$ Zrínyi Miklós várkapitány, illetőleg az altisztek, Radován Jakab és Szecsődi Máté is több falu birtokosai voltak. A források egyöntetű tanúsága szerint maga az erősség négy részből állt: a belső és a külső várból, az Óvárosból és az Újvárosból. Ezek együttes hossza körülbelül egy kilométer lehetett. Az Ó- és az Újvárost széles és mély árok vette körül, melyet az északkeleti irányból érkező Almás-patak két ágából töltöttek meg vízzel. A vízszint optimalizálását a város nyugati oldalán lévő 7,5-8 méter széles és 520 méter hosszú földtöltéssel oldották meg, mely felfogta, és tóvá duzzasztotta a vizet. Ezen a töltésen keresztül egy út vezetett ki a városból nyugati irányban. A délkeleti részen pedig, ahol a patak elhagyta a tavat, egy gát szabályozta a vízszintet. A tó az egykori vízrajzi viszonyokat figyelembe véve a vártól nyugatra 420-600, keletre 260-440 méter hosszan nyúlt el. ${ }^{22}$

A vár egy kissé magasabb térszinten helyezkedett el. Az Óvároshoz egy híddal kapcsolódott, de ez az erősség nem vizesárokkal volt körülvéve, hanem a tóvá duzzasztott térségből emelkedett ki. A belső s a külső vár között viszont húzódott egy mély, keskeny árok. A városból a várba vezető kapu a mai Vár utcában található 10. számú ház helyén állt. A várat tehát mocsaras talaj vette körül, mely az Almás-patak felduzzasztása által járhatatlan mocsárrá volt átváltoztatható. Ennek a mocsárnak a középső része szabad vízfelület volt, és észak felöl egy cölöpfallal akadályozták meg az elmocsarasodását. A szabadon álló részek alig emelkedtek ki a tó felszínéből. Ez a rendszer hatékony volt, de ellenálló képessége az évszaktól és időjárástól függött. ${ }^{23}$

19 Kováts Valéria készíttetett rekonstrukciót a várról a feltárásai alapján, mely azonban az újabb ásatások fényében nem pontos. Emellett számos réz- és fametszet áll a rendelkezésünkre, de ezek a késői nyugati mesterek által készült ábrázolások elég sematikusak. A török miniatúrák még kevesebbet árulnak el a 4 részből álló erősség részleteiről.

20 Budina 1978. 7.

21 Királyi sziget 1989. Ebből a forráskiadványból értesülünk Szigetvár várgazdaságáról a 1546-1565. években.

22 Sugár 1976. 42. és 165. Az új történeti források is megerősítik ezt a szerkezetet, Id. később.

23 Ez a rendszer jól látható a nyugati metszeteken is. 
Mindegyik egységet külön megerősítették gátakkal, árkokkal, mellvéddel, és a sarkokon rombusz alakú bástyákkal látták el őket. ${ }^{24} \mathrm{~A}$ bástyák háromszoros sövényfonadékból készültek, melyeket vasrudak és kötelek tartottak össze, közüket földdel töltötték ki. ${ }^{25}$ Elönye az volt, hogy ily módon sok lovast befogadó és így a törökök ellen hatékony erősségeket lehetett felépíteni, hátrányát viszont az jelentette, hogy harminc-negyven évente a tölgyfaoszlopok elkorhadtak, így újra és újra cserélni kellett őket. Hátránya volt még, hogy az ellenség könnyen felgyújthatta ezt a konstrukciót. A földgátak a várban és az Óvárosban hat méter magasak voltak, a mellvédek belső falai pedig két-három méter vastag téglafalból készültek. A gátfok magas és széles volt. Az Újvárosban viszont a falazat nélküli gátak alacsonyak voltak. A városba vezető utaknál sorompók helyezkedtek el, ezeknél kezdődtek meg 1566-ban az első előcsatározások a törökökkel. ${ }^{26} \mathrm{~A}$ törökök először az Újváros elfoglalását tűzték ki célul, de a többi egység ostromát is előkészítették, és egyidejü lövetésről is vannak adataink.

Az UUjváros palánkfalának délkeleti és délnyugati oldalán egy-egy földbástya helyezkedett el. Minden oldalról víz vette körül. A keleti felén ez a víztömeg csak egy keskeny árokban folyt, a nyugati részén azonban szélesebb ingovány övezte. Az Óvárossal széles és mély árkon át fahíd kapcsolta össze. Az Újváros déli oldalán állt a Siklósi kapu. A téglafalakkal és boltozattal épült kapuknál nem voltak tornyok, s a kapuk alagútszerüen vezettek ki a városból. Külső védőművei nem voltak. Istvánffy Miklós elég hevenyészettnek nevezte ezt a megerősítést, mely nagy sietve készült el Zrínyi Miklós várkapitány idejében. Emellett az Újvárosban faépítésü, szalmával fedett házakról tudósított, melyeket a törökök könnyen fel tudtak gyújtani. A városnak volt egy nagy piactere. A közelben körbekerített királyi kertek és gabonaőrlő malmok helyezkedtek el. A malmok kerítéseit Zrínyi Miklós azért gyújtatta fel, hogy a törököknek ne jelentsenek fedezéket. ${ }^{27}$ Az Újváros török rohama augusztus 7-én kezdődött meg a déli, vagyis a Siklósi kapunál, melyről ekkor még visszapattantak az ostromlók. A törökök kasokat fontak és földsáncot építettek, melyeket árokkal és földhányással erősítettek meg. Ide helyezték el az ágyúkat. ${ }^{28}$ Ahmed Feridun szerint a janicsárok, a ruméliaiak és az anatóliaiak kemény nyolcnapi rohamot intéztek minden oldalról az Újváros ellen..$^{29}$ Ágehi szerint az ostrom hatására pár nap küzdelem után a védők maguk gyújtották fel a várost körülvevő palánkot, és az Óvárosba húzódtak. ${ }^{30}$

Az Óvárosnak három bástyája volt. Északi és nyugati oldalán az előbb leírt tó, déli és keleti oldalán a tóból táplált vizesárok védte. A külső gátak falában helyezték el a kapukat és tornyaikat. Az Óváros nyugati vagy másként Patai-kapujától a gát tetején az előbb említett út vezetett Kanizsa felé. Ezen kívül a fő közlekedési úthoz vezető keleti, vagy másként Pécsi-kapu egy toronnyal is rendelkezett. A Patai és a Pécsi kapukat a török ostromkor a védők földdel betömték, hogy ellenállóbbá tegyék ezeket a kritikus pontokat. Az Óvárost kelet és dél felöl a vizesárok külső részén egy sánc is határolta. ${ }^{31}$ Viszont keleti oldalának hossza négyszáz méter volt, így a két keleti bástya túl távol került egymástól. ${ }^{32} \mathrm{Az}$ Óváros közepén, a piactéren, egy magaslaton állt a kéttornyú főtemplom. (A 17. századi metszetek egy részén már csak egy tornya ép.) Zsámboky János 1558. évi leírása szerint a város nyugati oldalán szintén gabonaőrlő malmok álltak, melyek minden valószínűség szerint 1566-ban is múködtek. ${ }^{33}$ Ez a városrész hatékonyan csak a keleti oldalról volt támadható, teljes nyugati oldalán a négyszáz-négyszázötven méter széles tó határolta. Északkeleti szögleténél egy tóparti vízimalom állt. A déli részén, az Újvárostól elválasztó palánkfalak és az árok mentén, a mai szigetvári Tinódi Lantos Sebestyén Általános Iskola udvarán 2010-ben volt egy kis ásatásunk, melynek során sikerült kimutatni az Újvárosba vezető kapu melletti vaskos középkori tölgyfaoszlopok helyét és a kisebb átmérőjü, más konstrukciójú, vékonyabb, kettős oszlopokból álló későbbi török palánkfal vonalát is. ${ }^{34}$

Ágehi szerint a janicsárok még az Óváros ostromával egy időben, augusztus 11-én átvágták a várostól nyugati irányba futó védő duzzasztógátat, és augusztus 17-én földet kezdtek bele hordani. ${ }^{35}$ Erre valószínűleg azért volt szükség, hogy a mocsár lecsapolása után az iszapot járhatóvá tegyék. ${ }^{36} \mathrm{Az}$ itteni török hadmozdulatok Istvánffy Miklós krónikájában találhatók meg a legrészletesebben: Ali Portuk török mérnök az ágyúkat az Újváros piacára vontatta, eléje sáncokat és kasokat helyezett, és az Óváros déli részét rendszeresen lövette. ${ }^{37}$

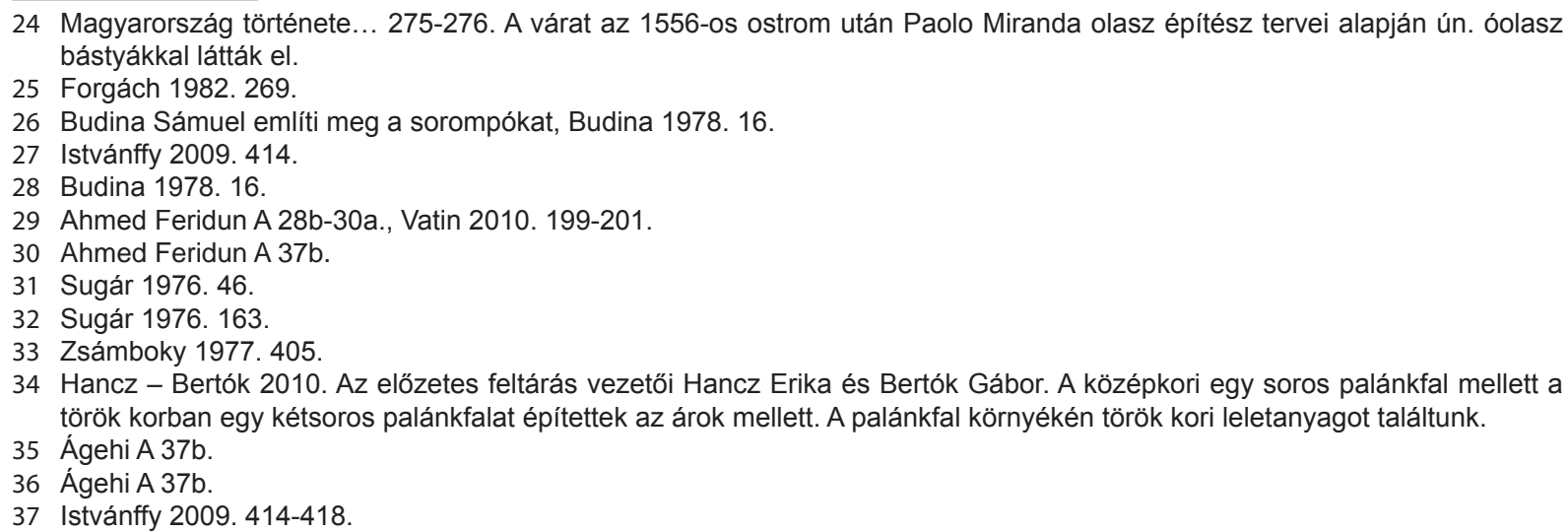


Ezzel párhuzamosan a keleti ágyútelepről, illetve a tó nyugati oldaláról az Óváros északnyugati részét és a délnyugati bástyát lőtték. Közben Ali Portuk a belső vár kör alaprajzú tornyán lévő harangot is eltalálta. Ha rövidebben is, de Budina krónikájában is szerepelnek ezek az események. Szerinte az Újvárosból augusztus 10-én már megkezdődött a három oldali török támadás. A törökök augusztus 19-én az Óváros keleti falán ütött résen keresztül betódultak a városba. A védők a város északi kapujához vonultak. A veszteségek hatására a védők jobbnak látták feladni az Óvárost, és visszahúzódni a külső vár területére. ${ }^{38}$

A várat az Óvárosból egy körülbelül száz lépést meghaladó, körülbelül százhatvan méter hosszú fahíd segítségével lehetett megközelíteni. ${ }^{39} \mathrm{~A}$ híd a város északi kapujától a vár délkeleti sarkához közeli főkapuhoz vezetett és középen védőtorony zárta le, mely egy zsilipnek is helyet adott. Itt a híd középső részén egy felvonóhíd is elhelyezkedett. A külső vár szabálytalan négyszög alaprajzú volt. A vár bástyáinak neve ismert: egyik bástyáját Zsámboky János szerint Henyei-bástyának nevezték. ${ }^{40}$ Ez Istvánffy szerint az ún. Tizedlő-kapun bemenőknek bal kézre állt. ${ }^{41} \mathrm{Mi}$ ezt az északkeleti bástyával azonosítjuk. Egy másik bástyát Hegyi-bástyának, illetve egy harmadikat a korábbi nádorispánról Nádasdy-bástyának neveztek el. ${ }^{42} \mathrm{~A}$ külső vár belsejében volt egy magas, tömör, kerek tornyokkal ellátott téglaépület, mely a várparancsnok háza volt, ezen kívül volt pár lakóház és raktár, egy szárazmalom, illetőleg egy tágas tér a belső vár középső részén. $A$ két vár közötti keskeny ároknál a belső vár erős gáttal volt megerődítve, a külső vár azonban csak alacsony

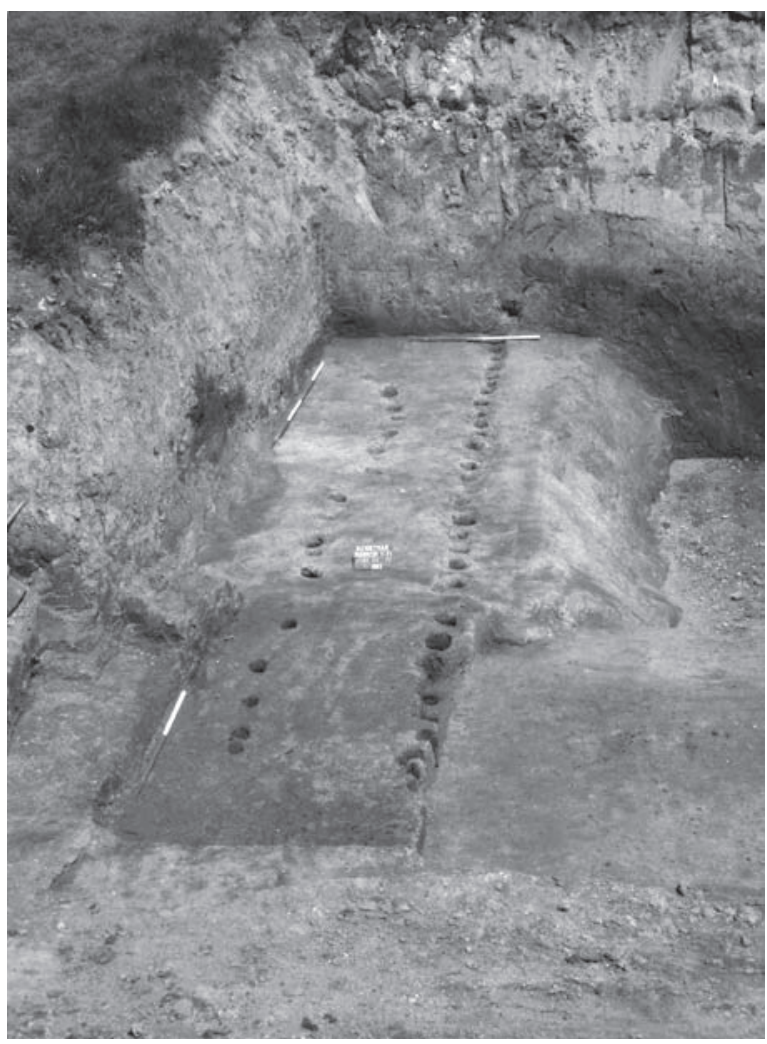

3. kép: a két soros török palánkfal az Újváros és az Óváros határán, 2010. évi ásatás, a Tinódi Lantos Sebestyén Általános Iskola udvara, Szigetvár, Rákóczi utca 9-13. (A szerző felvétele) fallal rendelkezett. A belső vár felé vezető árkon egy kicsi, keskeny fahíd vezetett át. A külső vár területén is folytak régészeti kutatások: a középkori maradványok az 1960-1962. évi Papp László és Kováts Valéria által végzett feltárások folyamán kerültek elő. Az északkeleti bástya területén 1-1,5 méter mélyen vízszintes gerendaváz és függőleges cölöpsorok jelentkeztek egy $25 \times 20$ méteres alapterületen, melyek a fapadlózat tartását szolgálták. A bástyaudvart ugyanis teljesen fapadlóval fedték le. A későbbi, barokk kori északi kazamatasor alatt a középkori magyar vár földbástyájának faszerkezet-vizsgálatát is elvégezték. ${ }^{43} \mathrm{~A}$ törökök többször is ostromra indultak a külső vár ellen, melyek részletesen ismertek a krónikákból. Az augusztus 26-i sikertelen ostrom után augusztus 29-én különösen heves ostromra indultak a törökök, hogy a szerencsenapjukon elfoglalják a várat. Aznap maga a szultán is lóra ült, és a janicsár hadtestnek ő adta ki a rohamra indító parancsot. Ebben a küzdelemben tüntette ki magát maga Ahmed Feridun is, ahogy krónikájában meg is jegyzi. ${ }^{44}$ Ekkor azonban még nem tudták elfoglalni. Azt, hogy hogyan jutottak be a törökök a külső várba, Szelániki leírásából így ismerjük: egy janicsár ezredes (bölükbasi) két bombával a vár északkeleti bástyájában felrobbantotta az egyik lőporraktárat, melynek következtében rés keletkezett a vár falán, így a törökök behatolhattak a várba.$^{45} \mathrm{Az}$ biztos, hogy valóban az északkeleti bástyánál jutottak be az ostromlók a vár területére. A keletkezett tűz ugyanis átterjedt a védők palánképítésére szolgáló faanyagára is. A vár sorsa ekkor dőlt el: Zrínyinek be kellett vonulnia a belső várba, hogy azt megóvja a tűztől. ${ }^{46}$

38 Forgách 1982. 271.

39 Sugár 1976. 43.

40 Zsámboky 1977. 406.

41 Istvánffy 2009. 418-420.

42 Istvánffy 2009. 418-420.

43 JPM Adattár nr. 1791-84. Kováts Valéria: Ásatási jelentés, Közép-és törökkori vár. 1961.

44 Ahmed Feridun A 34b-37a., Vatin 2010. 215-225. Ekkor kapott ziámetet.

45 Selâniki 1999. I. 31-32., Thúry 1981. 215-216. Ez az úgynevezett Nádasdy-bástya, ahol a törökök akna-ásással is próbálkoztak. A bomba kerámiából készült, nyílással rendelkező tárgy, melybe lőport és kanócot helyeztek. Hajítás során a kanóc tartotta benn a lőport a kerámiatestben. Kis hatásfokkal rendelkeztek ezek a bombák. Szétrepülő töredékeiket régészetileg szinte lehetetlen beazonosítani.

46 A külső vár ostromáról Ahmed Feridun müvében egy miniatúra található. 
Kováts Valéria régész 1961-62. évi ásatásainak többsége a belső vár területén, a mai északnyugati bástyaudvarban és annak környezetében folyt. Megtalálta a középkori vár kerek tornyát és támpilléres falának alapozását. Előkerült egy favázas kút is, valamint az 1566. évi falomladék, emberi és állati csontok és középkori kerámiatöredékek, valamint ágyúgolyók kíséretében. Megkutatta a belső és külső várt elválasztó vizesárkot is, mely bizonyíthatóan húsz-huszonöt méter széles volt. Az árok szélénél erősítő cölöpöket vertek le. Innen kerámia, csont és bőr leletek kerültek elő. A belső vár északnyugati helyzetű kerek épülete mellett egy 16. század eleji árokrendszer is napvilágot látott, benne hat fából készült talicskával, melyeket az ágyúgolyók szállítására és földhordásra használtak a védők. A falalap-vizsgálatok során kiderült, hogy a középkori vár a jelenlegi vár területénél némileg nagyobb volt. ${ }^{47} \mathrm{~A}$ külső és a belső várat elválasztó híd tartógerendái is napvilágra kerültek a régészeti feltárások folyamán. 2006-ban a korábbi ásatási adatokat Gere László hitelesítette és módosította. ${ }^{48} \mathrm{~A}$ középkorból megmaradt kerek torony tetején harang és óra helyezkedett el. Egy kis tér szélén házak, egy szárazmalom, egy fegyverraktár és ágyúsház is volt, egy kút, börtön és pince társaságában. A belső várhoz szervesen csatlakozó $L$ alakú középső várban, a vizesárok közelében állt a várkapitány lakóháza, az ebédlőház, a konyha, a kincstár, egy jégverem és egy pince. A külső várba vezető kapu felső szintjén a várkapitány helyettese, az alvárnagy lakott, valamint ez az erősség fegyverraktárként is működött. ${ }^{49}$

A belső várba zárkózott kb. kétszáz védő sorsa meg volt pecsételve: csak két nagyobb és tizennégy kisebb ágyújuk maradt, valamint ezer véka búzaliszt, melyhez nem volt elegendő sütőkemence. $A$ többi ágyú a törökök kezébe került, és ezeket mindjárt a védők ellen fordították. Egy téglával bélelt kút oltotta a védők szomját, melyet Kováts Valéria meg is talált az 1960-as években történő feltárásai során. ${ }^{50}$ Budina Sámuel leírta, hogy a külső vár fala a belső várat is körülfogta, és a külső vár felől nem védte semmi a belső

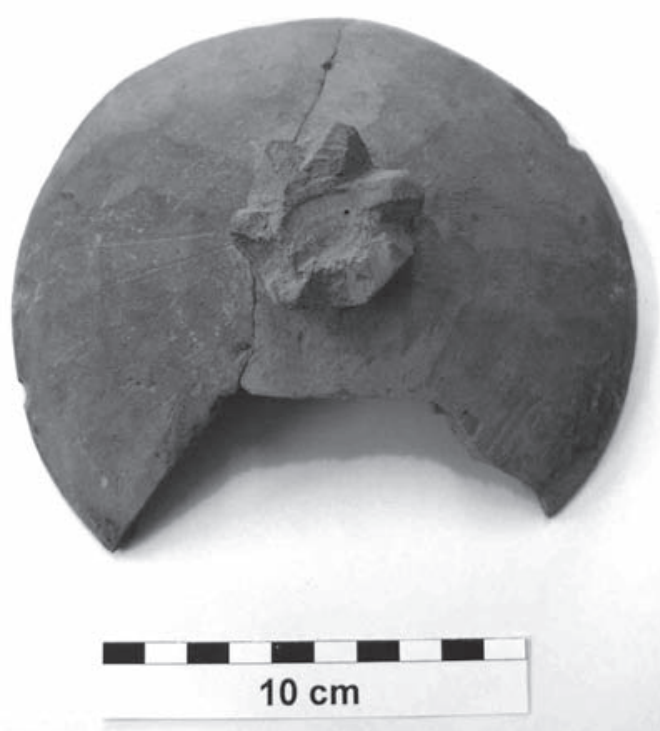

4. kép: Balkáni eredetű fedő töredéke. Szigetvár-Tinódi Lantos Sebestyén Általános Iskola udvara (A szerző felvétele) várat, így nagy veszélyben voltak a védők.

A régészeti adatok és a török források alapján tudjuk, hogy a falak és bástyák alacsonyak, de szélesek és maszszívak voltak. Kívül gerendákkal erősítették meg őket, melyeket vaskapcsokkal is összefogtak. Közüket földdel töltötték ki, kívülről agyaggal tapasztották be, vagyis palánkfal-szerűen épültek. A bástyák nagy alapterületűek voltak, hiszen a védők ágyúinak többsége itt foglalt helyet. 1566-ban a védők ebben a négyrészes erődítményben várták az ellenséges támadást. A mai téglavár ugyanis már később, a török időktől fogva épült ki. ${ }^{51}$

A belső várat övező vizesárok lecsapolása Pecsevinél fordul elő, szerinte a törökök „víztartó medencét" ástak, melynek következtében pár nap alatt lefolyatták a belső várat körülvevő vizet. Ezt követőn az iszapra földet és fát kellett hordani, hogy járható legyen..$^{52} \mathrm{~A}$ belső vár ellen a törökök általános ostroma augusztus 26 -án kezdődött el. Szelánikitől tudjuk, hogy a törökök a védők végső kirohanása előtti napon gallyakat halmoztak fel a vár tövében, és meggyújtották azokat. ${ }^{53}$ Erről nagyon röviden Ágehi is tudósított. ${ }^{54} \mathrm{~A}$ túzvészről a magyar források is beszámolnak. ${ }^{55} \mathrm{~A}$ névtelen szigetvári katona szerint egy asszony vigyázatlansága okozta azt a tüzet, melynek során a pinceboltozatba rejtett lőpor felrobbant. Hiába verték vissza a törökök rohamát, a hátuk mögött keletkezett tüz megpecsételte sorsukat. ${ }^{56}$

47 JPM Adattár nr. 1791-84.: ásatási beszámoló. Fennmaradtak az eredeti ásatási rajzok is, melyek segítségével az egyes régészeti objektumok visszakereshetők, JPM Adattár nr. 1803-84. Az eredményeket az ásató csak 1966-ban megjelent rövid ebb cikkben publikálta, Kováts 1966.

48 JPM Adattár nr. 2175-2007. Szigetvár - Vár, Kutatási dokumentáció, 2006. Gere László. A vár északnyugati bástyájában folyt a kutatás a Zrínyi-vár területén, Kováts Valéria ásatásának hitelesítő feltárása. Az eredmények kiadása: Gere 2007.

49 Sugár 1976. 44-46.

50 Kováts 1966. Az ágyúkról Id. Ahmed Feridun A 42b., Vatin 2010. 233.

51 A falak szerkezetére régészeti adataink is vannak, melyet „in situ” sikerült megfigyelni a feltárásaink során, Id. Hancz 2010. 77-78.

52 Tarih-i Peçevi I. 419., Török történetírók II. 78.

53 Selâniki 1999. I. 33-34., Thury 1981. 219.

54 Ágehi A 40b.

55 Bethlen 2002. 306. Ld. még: Budina 1978. 21.

56 Katona-beszámoló 164. 


\section{Összegzés}

Mivel láttuk, hogy a 16. századi Szigetvár kinézetére vonatkozóan milyen kevés konkrét adat áll a rendelkezésünkre, a PTE Régészet Tanszéke az Isztambuli Egyetem Múvészettörténeti Tanszékével együtt egy nagyszabású történeti-régészeti projektet indított el 2009-ben, illetve a Baranyai Megyei Múzeumok Igazgatóságának Janus Pannonius Múzeumával való együttmúködésben is végeztünk ásatásokat a város területén. A történeti adatok főleg a hadjárat lefolyásának rekonstruálásához szolgáltatnak alapot, az erősség szerkezetére vonatkozó régészeti kutatás pedig éppen hogy csak elkezdődött. A folyamatos projekt újabb állomásaként jelenleg Szigetvár Önkormányzatának támogatásával végezzük. Időben kiterjesztjük a már megkezdett forrásfeldolgozást, illetve műszeres felmérésekkel, terepmodellezéssel, ásatások szervezésével folytatjuk a terület régészeti kutatását is. Az eredményeket egy Szigetvár középkorát és török korát bemutató állandó kiállítás létrehozása mellett magyar, angol és török nyelven monográfia-szerúen is szeretnénk bemutatni. Ehhez egyrészt európai uniós, másrészt török műemléki támogatást veszünk igénybe. A monográfában a korábbi ásatások még nem publikált adatai, illetve a feltárt és feltárandó régészeti leletanyag feldolgozása is megjelennének. Terveink szerint 2016-ig, a szigetvári hadjárat 450. évfordulójára a kötetek napvilágot láthatnak.

\section{Szigetvár in the time of the 1566 Szigetvár campaign. Historical and archaeological investigations of the castle and the city}

\section{ERIKA HANCZ}

A lot of chronicles, newspaper issues and letters were written about the Szigetvár campaign of Süleyman the Magnificent (30 Sept. 1520 - 7 Sept. 1566) in different languages. But there are still a lot of archive documents and several chronicles about the Szigetvár campaign which remained less known or unknown or unpublished.

The major part of this examination was done with the help of the so called Sigetvar-nâmes, the separate Ottoman chronicles about the campaign. We have informations about nine Sigetvar-names which were written by different Ottoman scolars in the 16th century. I could find the manuscripts of only the first five on the list above (their have 15 manuscripts all together).The Sigetvar-nâmes are the followings: Âgehi Mansûr: Fetih-nâme-i kale-i Sigetvâr / Târih-i gazâ-i Sigetvâr, Ahmed Feridun: Nüzhetü'l-esrâri'l-ahbâr der sefer-i Sigetvâr, Gelibolulu Mustafa Âli: Heft meclis (Kânûnî'nin 974 Sigetvâr Seferi Târihçesi), Unknown author: Târih-i Sigetvâr/ Heft dâstân, Merâhi: Fetih-nâme-i sefer-i Sigetvâr, Âşık Çelebi: Sigetvâr-nâme, Seyfullâh Seyfi: Sigetvâr-nâme, Ali Mehmed Çelebi: Sigetvâr-nâme, Seyyid Lokman: Sigetvâr-nâme.

Beside these there are contemporary sources also about the Szigetvár campaign. Kâtib Mohammed Zâim: Câmiü't-tevârih, Mustafa Selâniki: Târih-i Selâniki, Hasanbeyzâde Ahmed: Tevârih-i Âl-i Osmân, Solakzâde Mehmed Hemdemî: Tevârih-i Âl-i Osmân, Ibrahim Peçevi: Târih-i Peçevi, Evlia Çelebi: Seyahat-nâme.

We have also letters and documents which exist in the archieves in Istanbul and Vienna. In 2009, Dr. Géza Dávid and Dr. Pál Fodor published the documents of the sultan's divan, concerning to Hungary in the 1564-65 years, the period just before the Szigetvár campaign. The mühimme defters from the first part of year 1566 were also published by the Turkish collagues. Unfortunately, the mühimme defter of the second part of the campaign does not exist. Beside these documents, we have also a big amount of letters in Ottoman, German, Latin and Hungarian language, concerning mainly to the antecedents and the aftermaths of the campaign.

The University of Pécs Department of Archaeology and the University of Istanbul's Department of Art History arranged collaboration aimed at finding Ottoman remains in the Szigetvár area from 2009. Beforehand, we checked through all the written sources in the Ottoman Prime Ministry Archive and at the State Archive in Vienna. The excavation results aside, we carried out ground survey and field walking operations in Szigetvár in the framework of the project. Evidence of the moat separating the Old Town from the New Town, and of the medieval and Turkish-era palisade walls, came to light during a preliminary excavation conducted by me and Gábor Bertók in the courtyard of the Tinódi Lantos Sebestyén General School in the spring of 2010. Now we are planning to make an exhibition about the medieval and Turkish period of Szigetvár, to do more historical researches about the events after the campaign and reconstruct Szigetvár in the lights of the earlier and future excavations and other methods of archaeology, financed by European and Turkish fonds. By 2016, when 450. anniversary of the campaign would be, we would like to present a book about the campaign and the Turkish period of the castle and city, and reconstruct the Süleyman mosque and the so called "Turkish house" in Szigetvár. 


\section{Irodalom}

Ahmed Feridun A.: Nüzhetü'l-esrâri'l-ahbâr der sefer-i Sigetvâr/Süleymân-nâme. Topkapı Sarayı Müzesi Kütüphanesi Hazine, nr.: 1339: 1b-147b.

Ágehi A.: Âgehi Mansur: Sigetvâr târihi. Sigetvar seferi tarihcesi, Agehi Mansur Çelebi. Millî Kütüphane Başkanlığı, Ankara Cebeci Illçe Halk Ktp., nr.: 06 Ceb 686: 1b-50a.

Arslantürk, H. A. - Kaçar, M. 2013.: Merahi'nin Fetihname-i Sigetvar'ı (Kanunu'nin Son Seferinin Şiirsel Anlatımı). Istanbul

Bethlen F. 2002.: Erdély története II. kötet. A váradi békekötéstől János Zsigmond haláláig (1538-1571). Budapest

Budina S. 1978.: Budina Sámuel históriája Szigetvár ostromáról. Ford.: Molnár Imre, Szigetvár

Dávid G. - Fodor P. 2009.: „Ez az ügy fölöttébb fontos.” A szultáni tanács Magyarországra vonatkozó rendeletei (1559-1560, 1564-1565). MTA Történettudományi Intézete. História Könyvtár - Okmánytárak 6., Budapest

Evlia 1318.: Evliyâ çelebî: Seyahatnâme VI. İstanbul

Evlia 1908.: Evlia cselebi török világutazó magyarországi utazásai 1664-1666. Kiadta: Karácson Imre, Budapest

Evlia 1985.: Evlia cselebi török világutazó magyarországi utazásai 1664-1666. Fodor Pál előszavával. 2. kiadás, Budapest

Evlia 2002.: Evliya çelebi Seyahatnâmesi 6. Cilt. Ed.: Kahraman, Seyit Ali - Dağlı, Yücel, Istanbul

Forgách F. 1982.: Emlékirat Magyarország állapotáról Ferdinánd, Miksa királysága és II. János erdélyi fejedelemsége alatt. XVI. könyv. Budapest

Gere L. 2007.: A szigetvári vár 2004. és 2006. évi ásatásának főbb eredményei. Müemlékvédelem 2007/1. 28-30.

Hancz E. 2009.: Nagy Szülejmán szigetvári hadjáratához kapcsolódó levelek a bécsi Staatsarchivban. In.: A kívánt világosság. VI. Nemzetközi Vámbéry Konferencia kötete. Dunaszerdahely, 138-164.

Hancz E. 2010.: Military Architecture in Turkish-era Hungary. In.: Exhibition on Ottoman Art. 16-17th century Ottoman Art and Architecture in Hungary and in the Centre of the Empire. Istanbul, 71-81.

Hancz E. - Bertók G. 2010.: A 2010-es szigetvári hódoltságkori régészeti kutatások. Várak, kastélyok, templomok IV/4. 20-22.

Hasanbeyzâde 2004.: Hasan Beyzâde Târihi I-III. Kiadta: Aykut, Şevki Nezihi, Ankara

Heft meclis A: Gelibolulu Mustafa Âli: Heft meclis. - TSM Ktp. Revan, nr.: 1290/2: 26b-40a.

Istvánffy M. 2009.: Istvánffy Miklós magyarok dolgairól írt históriája. Tállyai Pál XVII. századi fordításában. Sajtó alá rendezte: Benits Péter, Budapest

Katona-beszámoló: Egy végvári katona beszámolója Szigetvár elestéről. In.: Válogatás a magyar hadügy írásaiból. Budapest, 1986. 162-164.

Királyi sziget 1989.: Tímár György: Királyi Sziget. Szigetvár várgazdaságának iratai 1546-1565. Pécs

Kováts V. 1966.: Sziget várának kutatástörténetéhez. Janus Pannonius Múzeum Évkönyve 11. 207-255.

Magyarország története...: Magyarország története 1526-1686, 3/1, Szerk.: Pach Zsigmond Pál - R. Várkonyi Ágnes, Budapest, 1985.

Selâniki 1999.: Selânikî Mustafa Efendi: Tarih-i Selânikî (971-1003) I. Cilt. M. İpşirli (ed.). Türk Tarih Kurumu, Ankara

Solakzâde 1989.: Solak-zâde Tarihi. II. Cilt. Kiadta: Çabuk, Vahid. Ankara

Sugár I. 1976.: Szigetvár és viadala. Budapest

Târih-i Peçevi I: Peçevi, İbrahim: 1281-1283/1864-1866. Tārih-i Pečevi I. İstanbul Matbaa-i Amire

Thúry J. 1981: Szigetvár elfoglalása 1566-ban. Török forrás szerint. Egy rajzmelléklettel. Hadtörténeti Közlemények 209. 6080. és 208-225.

Török történetírók II.: Thúry József: Török Történetírók II. Kötet. Budapest, 1896.

Vatin, N. 2010.: Ferîdûn Bey: Les plaisants secrets de la campagne de Szigetvár. Wien

Zsámboky J. 1977.: Sziget ostromának rövidre fogott és hű előadása, amint azt a király számára a napról napra történtek alapján följegyezték, 1558. In.: Humanista történetírók. Szerk.: Kulcsár Péter, Budapest, 402-410. 
